\title{
Exenatide treatment causes suppression of serum fasting ghrelin levels in patients with type 2 diabetes mellitus
}

\author{
Metin Guclu', Sinem Kiyici', Zulfiye Gul' ${ }^{2}$ and Sinan Cavun ${ }^{2}$ \\ ${ }^{1}$ Health Sciences University, Bursa Yuksek Ihtisas Education and Training Hospital, Department of Endocrinology and Metabolism, Bursa, Turkey \\ ${ }^{2}$ Department of Pharmacology, Uludag University Medical Faculty, Bursa, Turkey
}

Correspondence should be addressed to S Kiyici: drsinemkiyici@gmail.com

\begin{abstract}
Aim: In the present study, we investigated the long-term effects of exenatide treatment on serum fasting ghrelin levels in patients with type 2 diabetes mellitus. other antihyperglycemic drugs on a stable dose for at least 3 months, were enrolled in the study. $\mathrm{BMI}>35 \mathrm{~kg} / \mathrm{m}^{2}$ and $\mathrm{HbA} 1 \mathrm{c}>7.0 \%$ were the additional inclusion criteria. Oral antihyperglycemic drugs, other than metformin, were stopped, and metformin treatment was continued at $2000 \mathrm{mg}$ per day. Exenatide treatment was initiated at $5 \mathrm{\mu g}$ per dose subcutaneously (sc) twice daily, and after one month, the dose of exenatide was increased to $10 \mu \mathrm{g}$ twice daily. Changes in anthropometric variables, glycemic control, lipid parameters and total ghrelin levels were evaluated at baseline and following 12 weeks of treatment.

Results: Thirty-eight patients (male/female $=7 / 31$ ) entered the study. The mean age of patients was $50.5 \pm 8.8$ years with a mean diabetes duration of $8.5 \pm 4.9$ years. The mean BMI was $41.6 \pm 6.3 \mathrm{~kg} / \mathrm{m}^{2}$ and the mean $\mathrm{HbA} 1 \mathrm{c}$ of patients was $8.9 \pm 1.4 \%$. The mean change in the weight of patients was $-5.6 \mathrm{~kg}$ and the percentage change in weight was $-5.2 \pm 3.7 \%$ following 12 weeks of treatment. BMI, fasting plasma glucose and $\mathrm{HbA} 1 \mathrm{C}$ levels of patients were decreased significantly $(P<0.001$ and $P<0.001$; respectively), while there was no change in lipid parameters. Serum fasting ghrelin levels were significantly suppressed following 12 weeks of exenatide treatment compared with baseline values $(328.4 \pm 166.8$ vs $245.3 \pm 164.8 \mathrm{pg} / \mathrm{mL})(P=0.024)$.

Conclusion: These results suggest that the effects of exenatide on weight loss may be related with the suppression of serum fasting ghrelin levels, which is an orexigenic peptide.
\end{abstract}

Key Words

- exenatide

- ghrelin

- diabetes

\section{Introduction}

Excess weight and weight gain are significant problems in the treatment of patients with type 2 diabetes mellitus (1). Weight reduction is a critical part of type 2 diabetic patients' management to obtain better glycemic control and prevent the development of chronic complications. Excessive energy intake is one of the contributing factors that play a part in the observed weight gain in patients with type 2 diabetes mellitus (2). In addition, many antidiabetic agents, including insulin, sulfonylureas and thiazolidinediones, cause weight gain instead of weight loss during the management period (3). Glucagonlike peptide-1 (GLP-1) receptor agonists are used in the
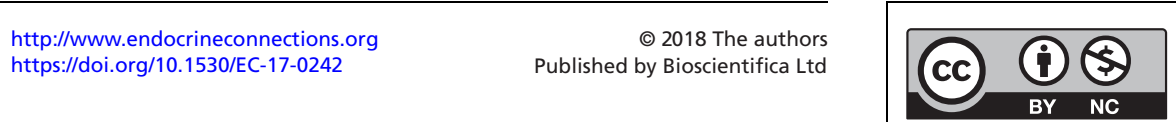
treatment of patients with type 2 diabetes mellitus, and liraglutide $3 \mathrm{mg} /$ day has also been recently approved for the treatment of obesity. GLP-1 agonists are potential regulators of feeding behavior through their ability to inhibit gastric emptying, reduce food intake and induce satiety $(4,5)$, but the exact mechanism of how GLP-1 agonists promote weight loss is not clearly understood.

Ghrelin, which is a potent gut-brain orexigenic peptide, plays an important role in the stimulation of food intake and long-term regulation of body weight $(6,7)$. Preprandial rise and postprandial fall in plasma ghrelin concentrations suggest a physiological role for ghrelin in meal initiation in humans (8). There are some limited animal and cross-sectional studies that suggest that suppression of serum ghrelin levels might be one of the contributing factors for the weight loss effect of exenatide. It was reported that exenatide, which is a long acting GLP-1 agonist, reduced serum ghrelin levels in fasting rats (9), and exenatide treatment caused prolonged suppression of serum ghrelin levels following a mixed meal test in obese diabetic women (10). However, there is no study evaluating the effects of chronic exenatide usage on serum fasting ghrelin levels. In the present study, we investigated the long-term effects of exenatide treatment on serum fasting ghrelin levels in obese patients with type 2 diabetes mellitus.

\section{Material and methods}

\section{Subjects}

This study was planned as an open-label, non-randomized, longitudinal study. Patients were recruited from prescreened patients with type 2 diabetes mellitus from an Endocrinology outpatient clinic of a tertiary referral center. Thirty-eight diabetic patients, who were using metformin with and without the other antihyperglycemic drugs on a stable dose for at least 3 months, were enrolled in the study. Body mass index (BMI) $>35 \mathrm{~kg} / \mathrm{m}^{2}$ and hemoglobin A1c $>7.0 \%$ were the additional inclusion criteria. Exclusion criteria included presence of pancreatitis, cardiovascular, gastrointestinal, hepatic, renal, rheumatological, neoplastic, infectious and other endocrine diseases, with the exception of type 2 diabetes mellitus, hyperlipidemia and hypertension. None of the patients had a previous history of substance abuse. Informed consent was obtained from all participants, and the study was performed in accordance with the Declaration of Helsinki. The study was approved by the
Local Ethical Committee of Yuksek Ihtisas Research and Training Hospital (formerly Sevket Yilmaz Research and Training Hospital).

At the beginning, standard diet and lifestyle modification, including physical exercise, were administered to all patients according to American Diabetes Association (ADA) recommendations (11). Patients were encouraged to implement medical nutrition therapy (MNT) modifications that reduce intakes of energy, saturated and trans fatty acids, cholesterol and sodium. Total energy intake was calculated as $25-30 \mathrm{kcal} / \mathrm{kg}$ for the ideal weight of a patient and was composed of $45-65 \%$ carbohydrates, $20-35 \%$ fat and $10-15 \%$ protein. Saturated fat and dietary cholesterol intake were limited to $<7 \%$ of total calories and $<200 \mathrm{mg} /$ day, respectively. A physical activity program was planned as $40-60$ min of walking at least 3 days per week. Oral antihyperglycemic drugs, other than metformin, were stopped and metformin treatment was continued as $2000 \mathrm{mg}$ per day.

After the 72-h washout period, patients presented to the investigation center in the morning following a 12-h fasting period. Body weight and height were measured in the fasting state. BMI was computed as weight in kilograms divided by height in meters squared. Blood pressure (BP) measurements were obtained from each patient's right arm in the seated position by using a standard mercury sphygmomanometer after $10 \mathrm{~min}$ of rest in the morning. Three successive BP readings were obtained at 5-min intervals and averaged. Venous blood samples were taken for the measurement of biochemical parameters and serum total ghrelin levels. Exenatide treatment was initiated at $5 \mu \mathrm{g}$ per dose sc twice daily, and after one month, the dose of exenatide was increased to $10 \mu \mathrm{g}$ twice daily. Patients were seen every month to control treatment compliance. Patients were questioned for side effects of the used drugs. After the three months of exenatide treatment, patients were invited to the study center again, and the experimental procedures were repeated.

\section{Measurements}

Blood was collected into serum separator tubes with clot activator. Samples were centrifuged at $3000 \mathrm{~g}$ for $15 \mathrm{~min}$ to separate serum. All specimens were stored at $-80^{\circ} \mathrm{C}$ until analysis. Serum total ghrelin levels were measured with the commercially available ELISA kit (RayBio Human/ Mouse/Rat Ghrelin Enzyme Immunoassay, RayBiotech, Norcross, GA, USA). The sensitivity limit of total ghrelin was $0.1 \mathrm{ng} / \mathrm{mL}$ and intra- and inter-assay coefficients of variability of the assay were $<10 \%$ and $<15 \%$, respectively. 
Baseline laboratory parameters, including serum glucose, total cholesterol, triglycerides (TG) and high-density lipoprotein (HDL) cholesterol, were measured using the auto analyzer system (Aeroset System Abbott, Abbott Laboratories) and HbA1c levels were determined by highperformance liquid chromatography (Trinity Biotech, Kansas City, MO, USA). Low-density lipoprotein (LDL) cholesterol was calculated by the Friedewald formula as total cholesterol- (HDL cholesterol+TG/5) in case of measured TG level below $400 \mathrm{mg} / \mathrm{dL}$. (For SI unit conversions: $\mathrm{pg} / \mathrm{mL} \times 0.3=\mathrm{pmol} / \mathrm{L}$ for ghrelin).

\section{Statistical analyses}

The data were analyzed using SPSS for Windows, version 21.0. Data were shown as mean \pm s.D. A two-sided $P$ value of less than 0.05 was considered statistically significant. Individual variables were compared by paired $t$ test for normally distributed variables and Wilcoxon signedrank test for non-normal variables. Percentage changes were calculated as (60th min-baseline)/baseline, (120th minutes-baseline)/baseline, etc. Pearson correlation analysis was used to investigate the association between serum ghrelin and the other laboratory parameters.

\section{Results}

Demographics, anthropometric measurements and laboratory parameters of patients at the beginning of the study and after the 12 weeks of treatment with exenatide plus metformin are summarized in Table 1. Thirty-eight patients (male/female $=7 / 31$ ) with type 2 diabetes mellitus entered the study. The mean age of patients was $50.5 \pm 8.8$ years with mean diabetes duration of $8.5 \pm 4.9$ years. All of the patients were obese, and the mean body weight was $108.1 \pm 17.6 \mathrm{~kg}$, while BMI was $41.6 \pm 6.3 \mathrm{~kg} / \mathrm{m}^{2}$. Baseline mean FPG was $225 \pm 79 \mathrm{mg} / \mathrm{dL}$ and mean $\mathrm{HbA1c}$ was $8.9 \pm 1.4 \%$, which reflects the uncontrolled diabetes. The lipid parameters of patients are often far away from the intended goal for diabetic patients. Serum mean LDL cholesterol and mean triglyceride levels were $115 \pm 45 \mathrm{mg} / \mathrm{dL}$ and $240 \pm 134 \mathrm{mg} / \mathrm{dL}$, respectively. Metformin and exenatide treatments were well tolerated by the patients, and we did not observe any serious side effects or major hypoglycemic events during the study period. All patients completed the study.

The mean change in weight of patients was $-5.6 \mathrm{~kg}$ and percentage change in weight was $-5.2 \pm 3.7 \%$ following 12 weeks of treatment, and it was considered as successful weight loss. The mean change in BMI of the patients was $-2.1 \mathrm{~kg} / \mathrm{m}^{2}$ at the end of the study $(41.6 \pm 6.3$ vs $39.5 \pm 6.3 \mathrm{~kg} / \mathrm{m}^{2}$ ). Significant differences were observed for both anthropometric parameters and $P$ value was $<0.001$. Mean changes were also statistically significant for FPG $(225 \pm 79$ vs $184 \pm 90)$ and HbA1c $(8.9 \pm 1.4$ vs $7.6 \pm 1.5 \%)$ levels during the study period, and $P$ values were 0.008 and $<0.001$, respectively. There was no change in lipid parameters, while significant differences were observed in SBP and DBP measurements. The mean change was $-9 \mathrm{mmHg}$ for SBP $(P=0.002)$ and $-4 \mathrm{mmHg}$ for DBP $(P=0.010)$. Serum fasting ghrelin levels were suppressed significantly at the 12th week of exenatide treatment compared with baseline values (328.4 \pm 166.8 vs $245.3 \pm 164.8 \mathrm{pg} / \mathrm{mL} ; P=0.024$ ) (Fig. 1 ). Normal hepatic and renal functions were preserved during the study period. Correlation analysis revealed that there was inverse but weak correlation between percentage change in serum ghrelin levels and percentage change in body weight $(P=0.01, r=-386)$. No significant, neither positive nor negative, correlation was found with serum ghrelin levels other than weight change.

Table 1 Laboratory parameters of patients at baseline and after the three months of treatment with exenatide plus metformin.

\begin{tabular}{l}
\hline \\
\hline Weight $(\mathrm{kg})$ \\
Body mass index $\left(\mathrm{kg} / \mathrm{m}^{2}\right)$ \\
Systolic blood pressure $(\mathrm{mmHg})$ \\
Diastolic blood pressure $(\mathrm{mmHg})$ \\
FBG $(\mathrm{mg} / \mathrm{dL})$ \\
HbA1c $(\%)$ \\
Total cholesterol $(\mathrm{mg} / \mathrm{dL})$ \\
HDL cholesterol $(\mathrm{mg} / \mathrm{dL})$ \\
Triglyceride $(\mathrm{mg} / \mathrm{dL})$ \\
LDL cholesterol $(\mathrm{mg} / \mathrm{dL})$ \\
Creatinin $(\mathrm{mg} / \mathrm{dL})$ \\
ALT $(\mathrm{U} / \mathrm{L})$ \\
Ghrelin $(\mathrm{pg} / \mathrm{mL})$
\end{tabular}

\begin{tabular}{c}
\hline Baseline $(n=38)$ \\
\hline $108.1 \pm 17.6$ \\
$41.6 \pm 6.3$ \\
$139 \pm 18$ \\
$86 \pm 10$ \\
$225 \pm 79$ \\
$8.9 \pm 1.4$ \\
$221 \pm 43$ \\
$43 \pm 9$ \\
$240 \pm 134$ \\
$115 \pm 45$ \\
$0.76 \pm 0.16$ \\
$25 \pm 17$ \\
$328.4 \pm 166.8$
\end{tabular}

\begin{tabular}{l}
\hline \\
\hline \\
\hline rd
\end{tabular}

3rd month $(n=38)$
$102.5 \pm 17.6$
$39.5 \pm 6.3$
$130 \pm 15$
$82 \pm 9$
$184 \pm 90$
$7.6 \pm 1.5$
$212 \pm 35$
$41 \pm 8.0$
$222 \pm 116$
$126 \pm 29$
$0.77 \pm 0.20$
$20 \pm 7$
$245.3 \pm 164.8$

\begin{tabular}{c}
$\boldsymbol{P}$ \\
\hline$<0.001$ \\
$<0.001$ \\
0.002 \\
0.01 \\
0.008 \\
$<0.001$ \\
NS \\
NS \\
NS \\
NS \\
NS \\
NS \\
0.024 \\
\hline
\end{tabular}

http://www.endocrineconnections.org https://doi.org/10.1530/EC-17-0242 


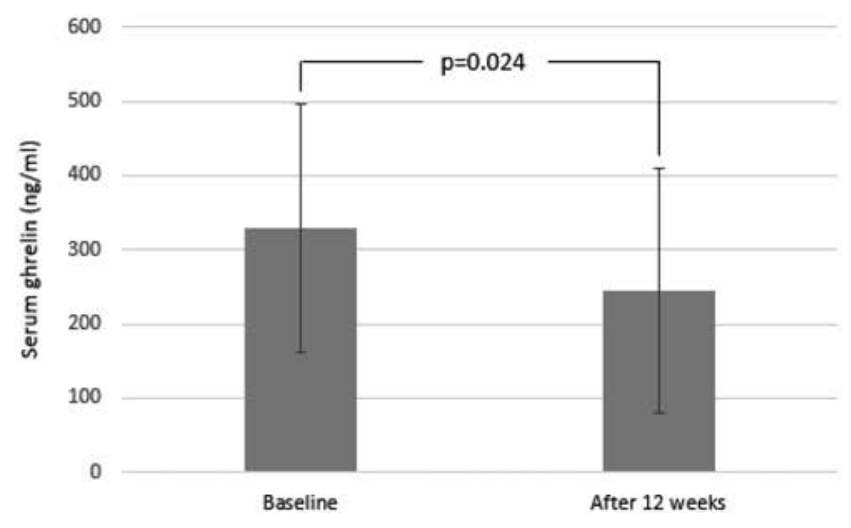

Figure 1

Effect of exenatide treatment on serum ghrelin levels of patients.

\section{Discussion}

In this study, we observed that serum fasting ghrelin levels were suppressed significantly following 12 weeks of exenatide plus metformin treatment in obese patients with type 2 diabetes mellitus compared with the baseline values. Body weight, BMI and HbA1c levels of patients were also decreased significantly. Exenatide is a glucoselowering drug that mimics the action of an endogenous GLP-1. GLP-1 receptor agonists, such as exenatide, increase the first phase of insulin secretion and suppress glucagon secretion, and it is effective in improving glycemic control $(4,12)$. Exenatide treatment also has been shown to induce weight loss in overweight patients with type 2 diabetes mellitus $(13,14)$. Exenatide is a potential regulator of feeding behavior through its ability to inhibit gastric emptying, reduce food intake and induce satiety $(4,5)$. But how exenatide exactly promotes weight loss and induce satiety is not clearly understood. Weight loss seen during the exenatide treatment is considered to be associated with the gastrointestinal side effects observed at the beginning of the treatment. However, several trials reported that patients who did not experience nausea also lose weight $(13,15)$. Our findings suggest that ghrelin suppression induced by exenatide treatment could be playing a role in the weight loss effect of exenatide.

Ghrelin is a potent orexigenic peptide and nutritional status can change endogenous ghrelin secretion. Serum levels of ghrelin increase in a fasting state and decrease after food intake. This is supporting the role of this peptide as a peripheral sensor of short-time energy balance $(16,17$, 18). It is suggested that increased serum ghrelin levels also have a role in weight regain after diet-induced weight loss. Recently, Sumuthiran and coworkers (19) reported that weight loss led to significant increment in serum levels of ghrelin. In addition, they observed a significant increase in subjective appetite of patients. Ghrelin also increases gastric motility and acid secretion (20). Ghrelin and GLP-1 have opposing effects on the gastrointestinal system when compared with each other. An inverse relationship between GLP-1 and ghrelin levels has been demonstrated after glucose ingestion in humans (21).

The effect of exenatide on serum ghrelin levels has been investigated in some animal studies. It is shown that combined treatment of exenatide with omeprazole reduces food intake and body weight gain, most likely through changes in plasma ghrelin and leptin levels in rats (22). Pérez-Tilve and coworkers (9) also reported that intraperitoneal and intracerebroventricular administration of exenatide reduced the serum ghrelin levels and the food intake in a dose-dependent manner in fasting rats. They showed that insulin levels also remained low for up to $8 \mathrm{~h}$ following exenatide administration.

Prader-Willi syndrome (PWS) is associated with hyperphagia and obesity. Patients with PWS have high circulating ghrelin levels that do not decrease postprandially (23). There are some studies evaluating the effects of GLP-1 receptor agonists in patients with PWS. Sze and coworkers (24) found that a single sc injection of $10 \mu \mathrm{g}$ exenatide increased satiety and lowered glucose and insulin levels but increased the insulin secretion rate in adults with PWS and in obese controls. They also reported that exenatide treatment decreased PYY and glucagonlike peptide-1, while ghrelin levels remained unchanged. However, Senda and coworkers (25) reported that the GLP-1 receptor antagonist, liraglutide, suppresses serum ghrelin levels and controls diabetes in patients with PWS.

However, there are limited data about the effect of exenatide treatment on serum ghrelin levels in patients with type 2 diabetes mellitus. Recently, it has been reported in a study which was designed in a cross-sectional manner (10) that exenatide treatment causes prolonged suppression in serum ghrelin levels following a mixed meal test in obese female patients with type 2 diabetes mellitus, but as far as we know, there is no study evaluating the effect of long-term exenatide usage on serum fasting ghrelin levels in patients with type 2 diabetes mellitus. Hagemann and coworkers (26) reported that a GLP-1 infusion suppressed ghrelin levels and increased insulin in healthy male volunteers. They concluded that the ghrelin reduction was likely a consequence of elevated insulin levels. When the effects of exenatide administration on serum insulin levels are taken into consideration, the observed serum ghrelin suppression might be secondary to the mentioned hormonal changes induced by exenatide in our study. Previous studies indicate that both increased insulin levels

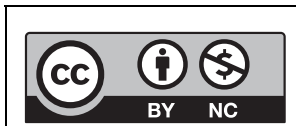

This work is licensed under a Creative Commons Attribution-NonCommercial 4.0 International License. 
and hyperglycemia suppress circulating ghrelin levels $(27,28)$. Serum glucose levels were lower compared with the baseline values in our study, but unfortunately, we did not measure serum insulin levels. However, it is known that exenatide treatment is lowering serum glucose and insulin levels while increasing the insulin secretion rate and insulin sensitivity, but this does not clearly explain the mechanism of the effect exenatide has on serum ghrelin levels. Another possible mechanism, which contributes to the postprandial decline in serum ghrelin levels, might be the delayed gastric emptying associated with exenatide treatment (29).

Patients in the present study were receiving both exenatide and metformin treatment. Metformin usage causes weight loss, but the results of the studies investigating the effect of metformin treatment on serum ghrelin levels are conflicting $(30,31)$. Suppression of serum ghrelin levels could not be attributed to metformin in our study because patients who were using metformin on a stable dose for at least 3 months were enrolled in the study, and metformin treatment was continued throughout the study.

In conclusion, these results suggest that 12 weeks of exenatide plus metformin treatment suppresses serum fasting ghrelin levels in obese patients with type 2 diabetes mellitus. However, our study population was small in order to draw a definitive conclusion with regard to the general population. Further randomized placebo controlled studies are needed to clarify the exact effect of exenatide and the other GLP-1 receptor agonists treatment on serum ghrelin levels in order to confirm our findings.

\section{Declaration of interest}

The authors declare that there is no conflict of interest that could be perceived as prejudicing the impartiality of the research reported.

\section{Funding}

This research did not receive any specific grant from any funding agency in the public, commercial, or not-for-profit sector.

\section{References}

1 UK Prospective Diabetes Study Group. U.K. prospective diabetes study 16: overview of 6 years' therapy of type II diabetes: a progressive disease. Diabetes 199544 1249-1258. (https://doi. org/10.2337/diab.44.11.1249)

2 Mäkimattila S, Nikkilä K \& Yki-Järvinen H. Causes of weight gain during insulin therapy with and without metformin in patients with Type II diabetes mellitus. Diabetologia 199942 406-412. (https://doi. org/10.1007/s001250051172)

3 Domecq JP, Prutsky G, Leppin A, Sonbol MB, Altayar O, Undavalli C, Wang Z, Elraiyah T, Brito JP, Mauck KF, et al. Clinical review: drugs commonly associated with weight change: a systematic review and meta-analysis. Journal of Clinical Endocrinology and Metabolism 2015 100 363-370. (https://doi.org/10.1210/jc.2014-3421)

4 Baggio LL, Huang QL, Brown TJ \& Drucker DJ. A recombinant human glucagon-like peptide (GLP)-1-albumin protein (albugon) mimics peptidergic activation of GLP-1 receptor-dependent pathways coupled with satiety, gastrointestinal motility, and glucose homeostasis. Diabetes 200453 2492-2500. (https://doi.org/10.2337/ diabetes.53.9.2492)

5 Shyangdan DS, Royle PL, Clar C, Sharma P \& Waugh NR. Glucagonlike peptide analogues for type 2 diabetes mellitus: systematic review and meta-analysis. BMC Endocrine Disorders 201010 20. (https://doi. org/10.1186/1472-6823-10-20)

6 Date Y, Kojima M, Hosoda H, Sawaguchi A, Mondal MS, Suganuma T, Matsukura S, Kangawa K \& Nakazato M. Ghrelin, a novel growth hormone releasing acylated peptide, is synthesized in a distinct endocrine cell type in the gastrointestinal tracts of rats and humans. Endocrinology 2000141 4255-4261. (https://doi.org/10.1210/ endo.141.11.7757)

7 Nakazato M, Murakami N, Date Y, Kojima M, Matsuo H, Kangawa K $\&$ Matsukura S. A role for ghrelin in the central regulation of feeding. Nature 2001409 194-198. (https://doi.org/10.1038/35051587)

8 Cummings DE, Purnell JQ, Frayo RS, Schmidova K, Wisse BE \& Weigle DS. A preprandial rise in plasma ghrelin levels suggests a role in meal initiation in humans. Diabetes 200150 1714-1719. (https://doi.org/10.2337/diabetes.50.8.1714)

9 Pérez-Tilve D, González-Matías L, Alvarez-Crespo M, Leiras R, Tovar S, Diéguez C \& Mallo F. Exendin-4 potently decreases ghrelin levels in fasting rats. Diabetes 200756 143-151.

10 Topyildiz F, Kiyici S, Gul Z, Sigirli D, Guclu M, Kisakol G \& Cavun S. Exenatide treatment causes suppression of serum ghrelin levels following mixed meal test in obese diabetic women. Journal of Diabetes Research 201620161309502.

11 American Diabetes Association. Standards of medical care in diabetes-2015. Diabetes Care 201538 (Supplement 1) 1-99.

12 Nauck MA, Kleine N, Orskov C, Holst JJ, Willms B \& Creutzfeldt W. Normalization of fasting hyperglycemia by exogenous glucagonlikepeptide-1 (7-36 amide) in type-2 (non-insulin-dependent) diabetic-patients. Diabetologia 199336 741-744 (https://doi. org/10.1007/BF00401145)

13 Kendall DM, Riddle MC, Rosenstock J, Zhuang D, Kim DD, Fineman MS \& Baron AD. Effects of exenatide (exendin-4) on glycemic control over 30 weeks in patients with type 2 diabetes treated with metformin and a sulfonylurea. Diabetes Care 200528 1083-1091. (https://doi.org/10.2337/diacare.28.5.1083)

14 Kim D, MacConell L, Zhuang D, Kothare PA, Trautmann M, Fineman M \& Taylor K. Effects of once-weekly dosing of a longacting release formulation of exenatide on glucose control and body weight in subjects with type 2 diabetes. Diabetes Care 200730 1487-1493. (https://doi.org/10.2337/dc06-2375)

15 De Fronzo RA, Ratner RE, Han J, Kim DD, Fineman MS \& Baron AD. Effects of exenatide (exendin-4) on glycemic control and weight over 30 weeks in metformin-treated patients with type 2 diabetes. Diabetes Care 200528 1092-1100. (https://doi.org/10.2337/ diacare.28.5.1092)

16 Nakazato M, Murakami N, Date Y, Kojima M, Matsuo H, Kangawa K \& Matsukura S. A role for ghrelin in the central regulation of feeding. Nature 2001409 194-198. (https://doi.org/10.1038/35051587)

17 Cummings DE, Purnell JQ, Frayo RS, Schmidova K, Wisse BE \& Weigle DS. A preprandial rise in plasma ghrelin levels suggests a role in meal initiation in humans. Diabetes 200150 1714-1719. (https://doi.org/10.2337/diabetes.50.8.1714)

18 Ariyasu H, Takaya K, Tagami T, Ogawa Y, Hosoda K, Akamizu T, Suda M, Koh T, Natsui K, Toyooka S, et al. Stomach is a major source of circulating ghrelin, and feeding state determines plasma ghrelin-like immunoreactivity levels in humans. Journal of Clinical

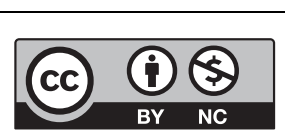

This work is licensed under a Creative Commons Attribution-NonCommercial 4.0 International License. 
controls diabetes in a patient with Prader-Willi syndrome. Endocrine Journal 201259 889-894. (https://doi.org/10.1507/endocrj.EJ120074)

26 Hagemann D, Holst JJ, Gethmann A, Banasch M, Schmidt WE \& Meier JJ. Glucagon-like peptide 1 (GLP-1) suppresses ghrelin levels in humans via increased insulin secretion. Regulatory Peptides 2007143 64-68. (https://doi.org/10.1016/j.regpep.2007.03.002)

27 Saad MF, Bernaba B, Hwu CM, Jinagouda S, Fahmi S, Kogosov E \& Boyadjian R. Insulin regulates plasma ghrelin concentration. Journal of Clinical Endocrinology and Metabolism 200287 3997-4000. (https://doi.org/10.1210/jcem.87.8.8879)

28 Flanagan DE, Evans ML, Monsod TP, Rife F, Heptulla RA, Tamborlane WV \& Sherwin RS. The influence of insulin on circulating ghrelin. American Journal of Physiology: Endocrinology and Metabolism 2003284 E313-E316. (https://doi.org/10.1152/ ajpendo.00569.2001)

29 Linnebjerg HS, Park PA, Kothare ME, Trautmann ME, Mace K, Fineman M, Wilding I, Nauck M \& Horowitz M. Effect of exenatide on gastric emptying and relationship to postprandial glycemia in type 2 diabetes. Regulatory Peptides 2008151 123-129. (https://doi. org/10.1016/j.regpep.2008.07.003)

30 Kiyici S, Ersoy C, Oz Gul O, Sarandol E, Demirci M, Tuncel E, Sigirli D, Erturk E \& Imamoglu S. Total and acylated ghrelin levels in type 2 diabetic patients: similar levels observed after treatment with metformin, pioglitazone or diet therapy. Experimental and Clinical Endocrinology and Diabetes 2009117 386-390. (https://doi. org/10.1055/s-0029-1220936)

31 English PJ, Ashcroft A, Patterson M, Dovey TM, Halford JC, Harrison J, Eccleston D, Bloom SR, Ghatei MA \& Wilding JP. Metformin prolongs the postprandial fall in plasma ghrelin concentrations in type 2 diabetes. Diabetes/Metabolism Research and Reviews 200723 299-303. (https://doi.org/10.1002/dmrr.681)

Received in final form 23 November 2017

Accepted 7 December 2017

Accepted Preprint published online 7 December 2017 http://www.endocrineconnections.org https://doi.org/10.1530/EC-17-0242
(C) 2018 The authors Published by Bioscientifica Ltd

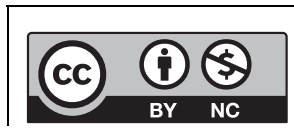

This work is licensed under a Creative Commons Attribution-NonCommercial 4.0 International License. 